\title{
IGREJA E CAROLÍNGIOS: NOVA IDÉIA DE ESTADO
}

Daniel Valle Ribeiro*

SINTESE - A criação do Regnum Francorum assinala o esvaziamento da idéia romana de Estado. Herdeira e sucessora de Roma, a Igreja promove a restauração da autoridade pública sob um novo conceito de poder. Os carolíngios são o instrumento para a realização da ideologia de um Império Criståo.
ABSTRACT - The creation of the Regnum

Francorum signals the disappearance of the Roman idea of State. Heir and successor of Rome, the Church promotes the restoration of public authority under a new concept of power. The Carolingians are the instrument for the fulfiliment of the ideology of a Christian Empire.

É conhecida a afirmação de que a morte do Império do Ocidente nas mãos dos bárbaros põe fim à idéia romana de Estado. $O$ primeiro reino germânico que se cria, o Regnum Francorum, estabelecido na Gália por Clóvis, é uma monarquia de caráter patronal e patrimonial. O soberano merovingio é o senhor que exige obediência e oferece proteção; é o proprietário - as terras pertencem ao rei por direito de conquista. A realeza não encarna uma magistratura. A concepção de Império, isto é, a noção de que o povo romano se identifica à pessoa de um homem que assume o encargo da defesa e da felicidade da Humanidade, é absolutamente estranha à monarquia franca. A realeza merovingia é antes de tudo "um Estado de fato, um produto da força". ${ }^{1}$ Inexiste a noção de direito público. A sucessão se processa segundo os princípios do direito privado. A partir de Clóvis, por exemplo, a divisão do reino obedece ao prescrito na Lei Sálica, como se tinha o costume de fazer com os bens de familia.

Para os romanos, entretanto, a respublica constituia a essência de sua concepção política. Fustel de Coulanges nota, em estudo de valor sempre atual, que "o principio fundamental de todo o Direito Público era a soberania absoluta do Estado. O Estado, ou a coisa pública, respublica, não era para os romanos uma concepção vaga". ${ }^{2}$ Fustel acrescenta que para eles respublica é uma composição de todos os

Universidade Federal de Minas Gerais - UFMG - Belo Horizonte.

1 LOT, Ferdinand, PFISTER, Christian, GANSHOF, François L. Les destinées de l'Empire en Occident. Histoire du Moyen Age. Paris: PUF, 1940. p. 298. (Histoire Générale de Gustave Glotz).

2 FUSTEL DE COULANGES, Numa Denis. "La monarchie romaine". In: —. Histoire des institutions. La Gaule romaine. Paris: Hachette, 1908. v. 1. p. 147 ss.

\begin{tabular}{|l|l|l|l|l|l|}
\hline VERITAS & Porto Alegre & v. 40 & $n^{2} 159$ & Setembro 1995 & p. $379-390$ \\
\hline
\end{tabular}


cidadãos, "um poder superior, uma autoridade mestra, ao qual todos deviam uma obediência sem limites", ${ }^{3}$ que resulta de uma delegação.

Esse ideal politico subsiste no Principado: O novo regime faz do imperador um magistrado que detém o imperium por delegação popular. O Império não é um poder pessoal, e acima do imperador está o Estado, isto é, a Lei. O príncipe é um depositário da autoridade delegada pelo povo. O Império Romano, portanto, não suprimiu a idéia de coisa pública.

Na verdade, o próprio Augusto se dizia o restaurador da República e se manteve fiel ao mos maiorum. Ele e seus sucessores do Alto Império deixaram subsistir a idéia de respublica que dominava os espiritos da época.

A anemia do pensamento político que se registra no momento da instalação do bárbaro no solo romano encontra apoio na desordem dos tempos da Gália merovíngia e na Itália lombarda do século VII. Ora, a noção de autoridade pública já entrara em colapso após Teodósio, e a não ser na época de Majoriano, o Baixo Império era cenário de insubordinação endêmica, anarquia palaciana e ineficiência de leis.

Em alguns povos germânicos vemos, porém, a retomada da noção de autoridade pública: Teodorico e vários de seus sucessores na Itália; os visigodos Leovigildo e Recesvinto legislaram com vistas ao bem público tanto quanto o fez Majoriano, 0 último imperador digno deste nome. Na legislação visigótica, aliás, verifica-se a existência de muitos princípios e disposições do direito romano. Isso é perfeitamente compreensível, diz P. D. King, ${ }^{4}$ porque, de todos os povos bárbaros, foram eles os que maior contacto tiveram com a civilização romana. No entanto, o próprio King adverte, é fácil exagerar o caráter romano do Codex Euricianus, sobretudo porque a maioria de suas disposições trata das transações comerciais.

Se a criação do Regnum Francorum gera um esvaziamento da idéia romana de Estado, o advento dos carolíngios, sob a tutela da Igreja, sustenta a noção de dever coletivo como fundamento da realeza. Com efeito, a doutrina política de Gregório Magno, retomada depois por Isidoro de Sevilha, afirma que o poder é um dever, uma missão, não um atributo pessoal ou mesmo um privilégio, e deve ser exercido em benefício da coletividade. Com Gregório surge a idéia de serviço. A teoria gregoriana da realeza cristã rompe com a idéia de poder pessoal, tão cara à Antiguidade. ${ }^{5}$

Isso nos remete, naturalmente, à idéia de um Império espiritual. De fato, a queda definitiva de Roma fez germinar uma esperança entre os romanos-itálicos: para "se consolarem da perda do Império eles tinham necessidade de acreditar que o momento histórico do Estado estivesse superado e que Roma tivesse de ressurgir sob nova forma". ${ }^{6}$ Assim é que já no último século do Império buscavam-se os fundamentos teóricos de um Império Romano-Cristão.

3 Idem, ibidem.

4 KING, P. D. Derecho y Sociedad en el Reino Visigodo. Madrid: Aliança Editorial, 1981. p. 27.

5 RIBEIRO, Daniel Valle. "A Realeza Cristã em Gregónio Magno". Varia Historia. Departamento de História - FAFICH/UFMG. Belo Horizonte, n. 12, p. 5-13, dez. 1993.

6 ARCARI, Paola Maria. Idee e Sentimenti Politici dell'Alto Medioevo. Milano: A. Giuffrè, 1968. p. 672. 
Sucessora de Roma, e agente de ligação entre o mundo antigo e a Idade Média, a Igreja irá ocupar, progressivamente, o espaço do poder imperial. A desordem que se seguiu às invasões fez, do bispo de Roma e demais bispos, líderes políticos que chefiavam a luta contra os bárbaros, que socorriam a população menos favorecida e protegiam os prisioneiros e os escravos. Em Roma, particularmente, é o papa quem aprovisiona e defende a cidade contra as invasões. Como inexiste um poder civil, o papado torna-se a única força capaz de fazer frente aos lombardos. 0 papa é o senhor da cidade e o único representante do Império. De tudo isso lhe advém grande prestígio. A Igreja acumula considerável patrimônio, graças a doações de reis e senhores: terras, isenções, rendimentos. Seus bispos pertencem, de modo geral, à alta aristocracia. Estabelece-se um estatuto privilegiado aos clérigos, que passam a usufruir de favores fiscais e a dispor de patrimônio, resultante de liberalidades. $\mathrm{O}$ apego do clero romano ao bem-estar é lamentado por Amiano Marcelino (XXVII). Também São Jerônimo estigmatiza com energia os estranhos abusos que a prosperidade crescente da Igreja romana introduzia em seu seio.?

A evolução da ideologia da Igreja-Estado compreende diversas fases e inserese na experiência política da Igreja. A cristianização do Ocidente e a sacralização do poder temporal, que se estendem do século VI ao IX, constituem importante momento do processo. Na realidade, a idéia da criação de uma Respublica Christiana consolida-se gradativamente: esboça-se na Antigüidade tardia, mas é na Alta Idade Média que toma forma definitiva. A fundamentação teórica de um Império espiritual encontra-se na referida doutrina política elaborada por Gregório Magno e Isidoro de Sevilha. De fato, ao atribuir um grau de sacralidade ao poder civil, Gregório e depois Isidoro têm em vista uma conçepção cristã do mundo. Como escreveu $M$. Pacaut, é essa filosofia politica que vai presidir, um século mais tarde, à construção do edifício carolíngio e mostrar de maneira significativa que existem muitos meios para um Estado cristão assim definido e sacralizado situar-se diante da autoridade eclesiástica. ${ }^{8}$

O Império Carolíngio encarna essa idealização. A aliança entre os carolíngios e a Santa Sé consubstancia-se com a criação da nova dinastia. Os fatos são conhecidos. Após consultar o papa Zacarias, Pepino, o Breve livra-se do último merovíngio e faz-se coroar rei. Mas não queria passar por usurpador e necessitava legitimar sua realeza. A unção que the conferiram os bispos francos imprimia-lhe a graça de Deus e dava uma aura de respeito ao seu poder. O papado, novamente ameaçado

7 DUCHESNE, Louis. Histoire ancienne de l'Église. 3. éd. Paris: Fontemoing, 1907. v. 2. p. 459.

8 PACAUT, Marcel. La théocratie. L'Église et le pouvoir au Moyen Age. Paris: Desclée, 1989. Assim P. M. Arcari vê a ideologia da Igreja-Estado: "Più che l'Impero era stato riconosciuto l'imperatore, al cui potere non si dava un fondamento razionale ma provvidenzialistico, facendolo discendere unicamente dall'arbitrio divino che si manifestava nella potenza stessa dell'imperatore. Ne consegui che il valore ideologico dell'Impero declinò col declinare della sua potenza storica". (ARCARI. Idee e sentimenti... p. 671 ss). É a melhor análise do equívoco teónico do Impéno Cristão. R. W. Southern, igualmente, julga que houve um erro teórico em tal esforço, ao escrever: "Il est évident, en fait, que l'idée d'un Empire occidental comme moyen d'élargir l'autorité papale fut une erreur du début à la fin. Ce fut une erreur d'abord parce qu'en créant un empereur, le pape ne créait pas un délégué mais un nval ou même um maître" (R. W. Southem. L'Église et la société dans l'Occident médiéval. Paris: Flammarion, 1987. p. 82. 
pelos lombardos na Itália, e sem contar com o apoio de Bizâncio, buscava apoio no Ocidente.

Em Ponthion (754) firma-se o acordo entre Pepino e o papa Estêvão II (752757). O pontífice consegue de Pepino a promessa de restituição das terras conquistadas pelos lombardos na Itália. $\mathrm{O}$ rei e seus filhos tornam-se patrícios dos romanos, isto é, protetores da cidade e da população de Roma. A segunda sagração solene de Pepino e a unção de seus filhos Carlos e Carlomano completam a aliança. Essa segunda sagração é "uma espécie de adoção espiritual" (H. Fichtenau). Estabelece-se a partir daí uma relação de "compaternidade" entre a realeza franca e o papado. Estêvão II fixa ainda o princípio de hereditariedade da familia de Pepino, ao ameaçar de excomunhão os que reconhecessem um rei fora da linhagem carolíngia. $O$ apoio da Igreja legitima a usurpação. $\mathrm{O}$ acordo de Quiercy faz o papa chefe de Estado. A criação do Estado Pontifício é, na expectativa do pontífice romano, uma garantia de segurança.

O rei franco é visto pela Sé Romana como um novo Moisés e comparado a Davi, chefe de um novo povo eleito. Roma atribui excepcional importância à realeza carolingia, como se vê na documentação emanada da chancelaria pontifícia. L. Halphen sublinha que "chez les Romains, le prince n'agit que comme dépositaire de l'autorité déléguée par le peuple. Le Carolingien tient son autorité de Dieu. Le sacre a fait de lui le chef désigné par Dieu pour guider vers le salut le nouveau peuple élu, le peuple chrétien". ${ }^{9}$

A aliança entre a Igreja e a realeza carolíngia dá origem a nova ideologia, que faz do soberano o chefe designado por Deus para conduzir até a salvação o novo povo eleito. O novo Saul reina sobre todo o povo cristão - omnis populus christianus - e é de sua responsabilidade promover o bem comum e a salvação. Governar bem significa cumprir todas as obrigações gerais, mas é sobretudo conduzir o povo à salvação eterna, sustenta Alcuíno. ${ }^{10}$

Carlos é, segundo as palavras rituais do papa Leão III, "coroado por Deus grande e pacífico imperador" - Karolo, piissimo Augusto a Deus coronato, magno et pacifico imperatore... (L P 1, 448). É a renovatio imperii, que acalentava o sonho de um Império Cristão. Note-se que a coroação do Natal de 800 atribui a Carlos Magno um poder universal destinado a proteger a Igreja, preservar a paz e conduzir os homens à salvação. Estamos, portanto, diante de uma realidade social mística: em sua estrutura jurídica, o Império; em seu aspecto interno, sua vida litúrgica e sacramental, a Igreja. ${ }^{11} \mathrm{O}$ que existe concretamente é um povo cristão, a um só tempo Igreja e Império, compreendendo uma realidade única. É praticamente impossível conceber um sem o outro. "Igreja e Estado formam um só corpo" (L. Halphen).

9 HALPHEN, Louis. "L'idée d'État sous le carolingiens". In: —_. A Travers I'Histoire. Paris: PUF, 1950. p. 94. Sobre o rito da sagração, cf. DAVID, Marcel. "Le serment du sacre du IXe. au XVe. siècle", Revue du Moyen Age Latin, Strasbourg, n. 6. janv.-mars 1950. 272 p. "Os monarcas da Idade Média tiveram consciência de deter um poder dotado de caráter supremo? Em caso afirmativo, interpretaram a prestação do juramento de sagração como um limite jurídico à sua soberania?", indaga M. David. Para responder a essas perguntas, diz, é necessário conhecer o texto do juramento não apenas de uma época ou de uma única regiảo, mas por um periodo que se estende de sua aparição até o fim do século XV e nos principais reinos cristãos (M. David. Le serment du sacre... p. 13).

11 PAUL, Jacques. L'Église et la culture en Occident. IXe-XIle siècles. Paris: PUF, 1986. v. 1. p. 63. 
Não se pode esquecer também que a coroação imperial de 800 , repetida depois em 875, legou "aux hommes d'Église comme aux princes du Xe. siècle deux notions impériales au premier abord peu conciliables: la première pourrait être qualifiée de "romaine" en ce qu'elle comportait, outre le sacre à Rome même, une titulature à l'antique d'imperator augustus, un ordo de couronnement à la fois tiré des usages pontificaux et des usages byzantins, et une notion d'universalisme de caractère chrétien; appelé par le pape à exercer une sorte de ministère sacré, l'empereur est béni par Dieu puisque sa mission est de protéger l'Église et les peuples". ${ }^{12}$

O príncipe detém uma potestas, que se origina do apoio dos homens livres que combatem. Mas era necessário assegurar o desvelo dos homens armados: esta, a origem dos juramentos de fidelidade que Carlos Magno impõe aos homens armados. Já em 789, através de um "aviso" endereçado aos seus súditos, Carlos determinava tarefas e atitudes a fim de que pudessem auxiliá-lo na realização de seus deveres de rei cristão. Na Capitular de 802 , os missi encarregados de sua execução são instruídos no sentido de esclarecerem sobre os deveres a serem assumidos pelos súditos do Império. Dentre as obrigações principais de quem presta o juramento, a primeira é a de que "se mantenha plenamente ao serviço de Deus[...] porque o imperador não pode, pessoalmente, dar a cada um em particular os cuidados necessários". ${ }^{13} \mathrm{Na}$ mesma linha de solidariedade com o soberano, o juramento estabelece ainda que nada se deve empreender contra a Igreja, as viúvas, os órfãos e os estrangeiros "porque o imperador é, após Deus e os santos, seu protetor e defensor" ${ }^{14}$ É através desses "avisos" que o soberano estabelece deveres para os seus súditos, de quem espera ajuda para realizar suas obrigações.

Carlos Magno, aliás, permaneceu sempre fiel à idéia de protetor da Igreja. Ora, como se sabe, para a mentalidade dos francos e dos germanos de modo geral, proteger tem significação rigorosamente ativa: "a proteção é autoritária e confere ao protetor o direito de intervir nos negócios do protegido"..$^{15}$ Decorrência natural, diante da Igreja a atitude do imperador, embora cercada de respeito, será sempre imperativa. Por outro lado, a insegurança geral predominante na sociedade favorece que exerça de imediato sua missão protetora. Carlos Magno rege a Igreja até em matéria disciplinar e doutrinária. Mesmo que estivesse persuadido da primazia papal, Carlos tinha absoluta convicção de que ele próprio governava o rebanho de cristãos para deixar um lugar ao exercício da jurisdição pontifícia. ${ }^{16}$ Não há dúvida, portanto, de que a balança de poder pendia para o lado do Estado. Estamos mesmo diante de um sistema de soberania única, verdadeiro cesaropapismo.

12 FOSSIER, Robert. "Recherche d'un équilibre". In: ——. Enfance de l'Europe. Apects économiques et sociaux. 2. éd. Paris: PUF, 1989. v. 2. p. 818. 94-5.

HALPHEN. Op. cit. p. 94

FOLZ, Robert. Le couronnement impériale de Charlemagne. Paris: Gallimard, 1964. p. 133.

CONGAR, Yves. L'ecclésiologie du Haut Moyen Age. Paris: Éd du Cerf, 1968. p. 202. Sobre a ação de Carlos Magno na vida da Igreja, cf. CARLYLE, A. J. A History of Mediaeval Political Theory in the West. London: Blackwood and Sons, 1903. v. 1. p. 258-67; AMANN, Émile. L'époque carolingienne. Paris: Bloud \& Gay, 1937. p. 77. (Histoire de l'Église, Fliche - Martin); SOUTHERN, R. W. L'Église et la société... p. 51-2. 
Carlos Magno tem sido visto freqüentemente como um rei-sacerdote. Há equivoco na afirmação. $O$ imperador não era sacerdote nem a realeza sacerdotal. Pemaneceu um chefe leigo, que detém um poder dado por Deus e que procura governar segundo os preceitos da teologia politica cristã. Ele estava persuadido de que era não apenas seu direito mas também seu dever como dirigente da cristandade cuidar dos negócios da fé. ${ }^{17}$

As mesmas prescrições de obrigações morais e espirituais aos súditos estão presentes nas capitulares de Luís, o Piedoso. Elas estabelecem estreita associação entre as prestações de serviço ao imperador e a coisa pública. Entretanto, a partir da ascensão do filho de Carlos Magno, é crescente a influência do episcopado na vida do Império, com a balança pendendo para o lado da Igreja.

Obviamente, a fraqueza do soberano propicia o fortalecimento do poder do alto clero. Mas não explica tudo. Existe um forte desejo, da parte do elemento eclesiástico, de ocupar um espaço, de libertar o poder religioso da dominação temporal. Chega-se mesmo a contestar vivamente a posição do imperador. Curiosamente, essa contestação parte do episcopado, não de Roma. A administração pública passa a ser regida segundo a óptica do moralismo. Os clérigos erguem-se em juízes severos do governo, ditam normas e se dispõem a advertir sobre os perigos que cercam o reino confiado a Luís. A tal ponto chega a ingerência dos homens da Igreja nos negócios públicos, que se traça abertamente um verdadeiro programa de reforma do Império.

Note-se que a nova ideologia se inspira no agostinismo político, isto é, a organização do reino terrestre segundo o modelo da cidade celeste. Na verdade, os bispos não desejavam diminuir a competência do Estado nem enfraquecer a autoridade imperial. Até porque são favoráveis à idéia de Império revestida de princípios cristãos. $O$ que os dignitários religiosos pretendem é um lugar saliente no Estado.

O protetorado episcopal que se ensaia busca expressar a supremacia do espiritual através da auctoritas, com base na doutrina gelasiana. O sinodo de Paris (829) reflete muito bem isso. Os bispos começam por definir o poder. Declaram que o príncipe recebe seu poder de Deus, segundo o que afirmara Gelásio. Insistem no primado do espiritual, de onde se retira a superioridade da ordem sacerdotal, com fundamento na diferença entre a auctoritas da Igreja e a potestas real ou imperial. Interpretam, porém, de maneira confusa o texto gelasiano ao concluírem que apenas a Igreja detém a verdadeira soberania. Após definir o poder, traçam o perfil do príncipe ideal de acordo com os preceitos de uma moral mais exigente: primar sobretudo por uma vida virtuosa. Desse modo, o soberano aparece como o modelo aos seus fiéis, não em virtude de seus triunfos ou de sua capacidade para governar, mas porque ele é a imagem por excelência do comportamento virtuoso. Os bispos exigem ainda amplas reformas na atividade política e religiosa. $\mathrm{O}$ texto final

17 H. Fichtenau faz critica severa a essa concepção. Cf. FICHTENAU, Henri. L'Empire carolingien. Paris: Payot, 1958. p. 83-4. Segundo Arquillière, "la forte notion de l'État forgée par les Romains, fondée sur le Droit naturel, semble se diluer et s'absorber dans la haute fonction religieuse exercée par Charlemagne. Jusqu'à présent, nous avons vu ce résultat s'ópérer peu à peu surtout dans la doctrine ecclésiastique". ARQUILUİ̈RE, Henri-Xavier. L'augustinisme politique. Essai sur la formation des théories politiques du Moyen Age. 2. éd. Paris: 1955. p. 159. 
do sinodo, verdadeiro tratado do sistema hierocrático, tem como redator principal Jonas de Orleans, que o retoma no seu De institutione regia. ${ }^{18}$

Como explicar essa nova reflexão sobre o governo e a moralidade? A nova atitude não parece ligada a acontecimentos do período de Luís. Denegação de justiça e abusos não teriam sido maiores que os da época de Carlos Magno. Seriam até menores, mas se tornaram intoleráveis. Tal verificação condicionaria uma evolução da mentalidade, capaz de explicar a mudança de atitude. Nessa hipótese, esse moralismo rigoroso e intransigente resultaria da reforma da Igreja e da renovação cultural. ${ }^{19}$

Por essa remodelação da moralidade, através dessa busca da conversão dos costumes, procuram-se novos contornos do poder, em esforço comum para melhor alcançar a plenitude da vida cristã. Esse saneamento moral do grupo imperial mostra bem o estado de espírito da época. Os bispos são críticos impiedosos do governo e da administração. Erros reais ou presumidos de Luís, o Piedoso eram motivo de censura rigorosa e constituiam faltas morais graves. Exclusivo intérprete autorizado das Escrituras, o clero exerce verdadeiramente importante papel. No entanto, ao lançarem seu grito de reforma das sociedades civil e religiosa, os bispos sofrem a tentação do poder. Desviam-se do seu ministério espiritual e tomam partido, depois, nas lutas entre os herdeiros do poder imperial. Alguns deles, tal como Agobardo de Lyon, têm conduta prepotente. As cartas deste prelado a Luís, o Piedoso são extremamente ásperas. ${ }^{20}$ Sem dúvida, o episcopado inspira e controla a política.

As graves perturbações que se seguiram à sublevação dos três filhos do imperador, em 830, por questões de partilha, culminam três anos depois com a derrota do próprio Luís, acusado ainda de arruinar a unidade imperial. Na suposição de que sua presença pudesse contribuir para restabelecer a paz, o papa Gregório IV (827-844) desloca-se para a Francia. O imperador acaba deposto por um golpe de Estado preparado pela facção de aristocratas leigos e eclesiásticos e novamente é forçado a fazer penitência para salvar sua alma. Agobardo e Ebbon, arcebispo de Reims, prepararam cuidadosamente essa mise en scène. Os bispos afirmavam que o soberano "foi subitamente privado do seu poder imperial por um julgamento de Deus", e devia, por haver faltado aos seus juramentos, ser acusado de ter cometido perjúrio. Na Assembléia de Compiègne, Luis perde o poder (833) e a seguir, conduzido à igreja de São Medardo de Soissons, despoja-se da dignidade imperial e recebe o hábito de penitente. É o ato final de uma "comédia sinistra" (R. Folz). ${ }^{21}$

18 REVIRON, Jean. Les idées politico-religieuses d'un évêque du IXe. siècle. Jonas d'Orléans et son "institutione regia". Paris: J. Vrin, 1930. Cf, também SOUZA, José Antônio C. R. de. "Raízes da Hierocracia no De Institutione Regia de Jonas de Orleans", In: Leopoldianum, Santos, v. 15, n. 44, p. 10145, dez. 1988. Sobre a doutrina hierocrática, cf. ULLMANN, Walter. Historia del Pensamiento Político en la Edad Media. Barcelona: Editorial Airel, 1983. p. 97-123.

21 Sobre a professio e os limites jurídicos do poder monárquico na época carolíngia, cf. DAVID, Marcel. La souveraineté et les limites juridiques du pouvoir monarchique du IXe. au XVe. siècle. Paris: Libr. Dalloz, 1954. p. 105 ss. Sobre as penitências e a deposição de Luís, o Piedoso, cf. especialmente as p. 112-19. 
A preponderância do elemento eclesiástico no Estado e sua intromissão nos problemas internos da monarquia favoreciam o enfraquecimento da autoridade imperial. Não se pode negar: os bispos agiam como intérpretes da vontade divina para derrubar o imperador. Mas qual foi o motivo invocado para justificar sua queda? Foi sua derrota diante dos filhos rebelados. Somente eles, os bispos, sentiamse habilitados a oficializar aquilo que Deus havia desejado. Posição idêntica tem Gregório IV, ao afirmar que toda a sociedade está sob a jurisdição espiritual da Igreja. Sustenta que "o governo das almas, que pertence ao pontífice, é mais importante que o governo temporal, que pertence ao imperador". ${ }^{22}$

Em nome da autoridade da Igreja, Luís, o Piedoso sofreu humilhação e afronta. Nos excessos que se cometem misturam-se confusamente preeminência espiritual, competência moral da Igreja, pretensão de soberania e luta pelo poder. As disputas pelo trono imperial, das quais participaram ativamente expressivas figuras do episcopado, acabaram por arruinar o prestígio do imperador. Apesar de haver recuperado o trono, a autoridade de Luís estava enfraquecida. É inegável: o poder espiritual desviou-se do seu objetivo e se transformou em arma na luta encarniçada a que se entregaram os herdeiros do Império.

Apesar da tutela exercida pelos bispos e a importância do seu papel nos acontecimentos, isso não foi sempre decisivo, uma vez que tiveram de tomar posições e escolher um campo: a politica acabou por dividir o episcopado e gerar desilusões. ${ }^{23}$

A divisão do Império pelo Tratado de Verdun (843) não apaziguou os herdeiros, que prosseguiram em suas disputas. Os bispos de cada reino, por sua tarefa de conselheiros, procuram assegurar a legitimidade do poder do seu soberano. Assim é que quando Luís, o Germânico invadiu o território do seu irmão Carlos, o Calvo, em 858, os bispos desse reino opuseram forte resistência e dirigiram a Luís enérgica carta, redigida por Hincmar, arcebispo de Reims. O documento contesta as pretensões do Germânico e assevera que Carlos não será destituido do reino porque o recebeu legitimamente pelo consentimento do povo e foi ungido pelos bispos. ${ }^{24}$ Estes não podem, sem argumento sério, destituí-lo. Esse documento "résume parfaitement le "systme épiscopal" affirmé depuis 814 et surtout depuis les années 830, ce d'autant plus que, dans ce même temps, Hincmar et d'autres réagissent contre certaines prétentions du pape à s'introduire dans ces affaires et affirment la responsabilité fondamentale de l'épiscopat auprès du roi". ${ }^{25}$ É importante observar que a sagração, invocada, toma significado político. Demais, dois outros elementos entram na consideração dos bispos - o julgamento de Deus e a moral.

A segunda metade do século IX é dominada por Hincmar, o mais competente canonista do seu tempo. $\mathrm{O}$ arcebispo de Reims proclama com energia a absoluta independência da Igreja em relação à realeza ao afirmar que, "se o rei é cristão e deseja governar segundo Deus, deve ouvir os conselhos dos bispos". Afirma que é a sagração, ato episcopal e espiritual por excelência, que confere a dignidade real. No sínodo de Sainte-Macre (881), que ele preside, os bispos afirmam que a digni-

MGH. Epistolae V, 228.

J. PAUL. Op. cit. p. 70.

MGH. Capitularia II, 451.

M. PACAUT. La théocratie. p. 42. 
dade dos pontífices é superior à dos reis porque "os reis são sagrados pelos pontífices, enquanto os pontífices não podem ser sagrados pelos reis" - Et tanto est dignitas pontificum major quam regum, quia reges in culmem regium sacrantur a pontificibus, pontifices autem a regibus consecrari non possunt. ${ }^{26}$ As duas afirmações completam-se e têm o claro objetivo de exaltar a autoridade episcopal.

Hincmar sustenta a idéia de unidade espiritual da Igreja, com vocação universal, fundada no Corpo do Cristo. Não concebe, entretanto, essa unidade sob a forma de monarquia pontifícia. Cristo instituiu o primado universal de São Pedro e também escolheu outros apóstolos de que os bispos são os sucessores. Para ele, a soberania está em Cristo. Na teologia hincmariana é plena a união entre o corpo eclesiástico e o corpo eucarístico de Cristo. Afirma com freqüência a fórmula de Leão I segundo a qual os cânones dos concilios "estabelecidos pelo espirito de Deus e consagrados pela veneração do universo" instituíram os metropolitanos à frente das províncias. A Igreja universal é constituída do conjunto de igrejas locais, unidas na mesma fé. Sua idéia de universalidade baseia-se em múltiplas unidades reunidas em uma. A unidade da Igreja resulta de um acordo tácito dos fiéis, com base na fé. Assim, para o arcebispo de Reims a Igreja é comunhão. ${ }^{27}$

Hincmar tem noção precisa da diferença de competência entre o sacerdócio e a realeza. Não pretende esmagar a autonomia dos soberanos. Deseja mesmo que mantenham sua independência sobretudo diante da Sé Romana. Segue a doutrina gelasiana de dualismo e cooperação entre os poderes, apenas não renuncia à sua condição de mentor espiritual do reino. Conhece o texto de Gelásio (de anathematis vinculo. Thiel Tract. IV, 557) e o repete, ao proclamar que Cristo é o único e completo rex et sacerdos ${ }^{28}$ e que depois dele nenhum rei é mais sacerdote e nenhum sacerdote pode reivindicar a função real. Julga que a vinda do Cristo é fundamental porque assinala uma ruptura na história da humanidade, pois associa 0 homem à eternidade de Deus. Ora, essa idéia vai informar toda a filosofia política do Ocidente medieval. A função real está intimamente associada à concepção da sociedade, isto é, à noção de dualidade na unidade, da união de dois elementos rei/imperador e bispo - para a realização de uma obra comum. ${ }^{29}$

Preocupado com os perigos que rondam o poder, adverte os soberanos que acima deles está o Rei dos reis (Rex regum), ao qual devem servir com temor, seguindo seus preceitos e não se afastando de uma vida justa. ${ }^{30} \mathrm{~A}$ conduta moral do rei serve de exemplo e por ela a sociedade modela o seu comportamento. Lembra ainda que os bispos, incumbidos de velar pelos reis, estão sujeitos às leis promul-

26 Capitula in Synodo. MANSI, 538. A cerimônia de sagração é, para Hincmar, um reflexo da unidade entre os dois poderes, Sacerdotium e Imperium. Sobre Hincmar e a evolução do programa hierocrático, cf. o excelente estudo de DEVISSE, Jean. Hincmar, Archevêque de Reims. 845-882. Genève: Libr. Droz, 1976. 3 v.

27 Sobre a eclesiologia de Hincmar, cf. Y. Congar. L'ecclésiologie... p. 166-77.

28 PL 126, 24-5. De ordini palatii 4. MGH c. 2, 519. Sobre a responsabilidade reciproca entre os dois poderes, cf. a análise crítica de Y. Congar. Op. cit. p. 254 ss.

29 Cf. Y. Congar. Op. cit. p. 262-66. Sobre a idéia de unidade entre regnum et sacerdotium, cf. CARLYLE. A History of Mediaeval Political Theory. v. 1, cit. p. 255-57.

30 De ordini palatii c. 2. 
gadas por Deus (leges divinitus promulgatas). A elas estão sujeitos todos os sacerdotes e a ninguém é permitido transgredi-las - reis ou ministros. ${ }^{31}$

Hincmar não elaborou uma obra específica sobre doutrina política, nunca expôs sistematicamente suas idéias, mas deixou numerosos escritos. J. Devisse oferece-nos excelente estudo do pensamento do arcebispo acerca da realeza. O prelado tem idéias muito pessoais, sem deixar de apoiar-se em predecessores de indiscutivel autoridade. Gregório Magno é de longe o mais solicitado. ${ }^{32} \mathrm{~A}$. originalidade maior de Hincmar está na sua definição do poder real. Eleito por Deus, o rei está ligado ao poder como cada homem, mas em grau mais alto, em virtude de seu cargo. Por uma obrigação contratual, o rei liga-se aos homens e instituições humanas. Para Hincmar assume especial importância o respeito à lei, a que está sujeito o soberano por dever, por um contrato moral com Deus. ${ }^{33}$ Por isso, o arcebispo faz da promessa de sagração um precedente da unção. Com efeito, a unção real é um rito de participação, de interação. É através dela que se especifica o poder do rei e se identifica a função real com a dos bispos. O soberano é agora homem da Igreja, unido espiritualmente ao seu reino.$^{34} \mathrm{O}$ rei tem, igualmente, compromisso com os que lhe são fiéis, base da própria ordem social desejada por Deus. O rompimento desse compromisso, por parte do rei, implica violação da ordem divina. Torna-se tirano aquele que não respeita a lei moral, viola as leis humanas e negligencia suas promessas. Hincmar retoma ensinamentos de seus predecessores, ao afirmar que 0 rei deve governar segundo os preceitos do cristianismo.

Os que cometem faltas graves, sejam jovens ou experimentados soberanos, merecem a censura do prelado. "Leur imposer des conseillers sages - l'archevêque a, bien évidemment, vocation à jouer ce rôle! - fait partie du devoir d'État pour le métropolitain rémois", nota J. Devisse. ${ }^{35}$

Portanto, o rei cristão está sujeito a regras morais. A violação dessas constitui falta grave. O desrespeito a leis humanas sujeita o monarca, homem como os outros, a sanções dessas mesmas leis. ${ }^{36}$ Ele não deve nem pode agir arbitrariamente, não é livre para renunciar a seus compromissos. As decisões do rei estão livres de qualquer controle, a não ser de natureza moral. Por isso, goza de total liberdade para decidir, sujeitando-se, obviamente, apenas às normas ordenadas pela Igreja. Enquanto instrumento de equilíbrio social, através do correto exercício de sua função real, a obediência ao príncipe deve ser absoluta: obedecer ao rei que é realmente rei é obedecer a Deus. ${ }^{37}$ Aos olhos de Hincmar, um rei injusto deve ser julga-

31. Idem, ibidem cc. 7, 8, 9 .

32 J. DEVISSE. Hincmar. p. 681-2.

33 PL 126, 119.

34 Y. Congar. (Op. cit. p. 283) lembra que para Hincmar "l'intervention sacerdotale dans le sacre manifestait seulement ce que Dieu lui-même opérait". J. Devisse (Op. cit. p. 703, n. 190) tem opiniäo idẻntica, em oposição à de $\mathrm{M}$. Bloch, que, ao analisar a posição de Hincmar, não se refere à estrita separação que este faz entre rex e sacerdos. Cf. BLOCH, Marc. Les rois thaumaturges. Paris: Gallimard, 1983. p. 71-3. De sua parte, o papa Joäo VIII julga que a cerimônia era caracteristica da função imperial.

35 J. DEVISSE. Op. cit. p. 692.

36 PL 125, 700-701.

37 PL 126, 98. 
do pela Igreja. Essa autoridade da Igreja, de caráter sagrado, exercida no plano político, é antes de tudo uma autoridade moral. Realiza-se principalmente através do conselho e do controle do governo civil pelos bispos. O julgamento de Deus e a moral são, aliás, importantes elementos de reflexão para os homens da Igreja. De sua parte, Carlos, o Calvo mostra-se disposto a aceitar essa concepção de poder, ao escrever (859) que, tendo sido sagrado nas formas exigidas, não deve ser suplantado nem destronado sem ao menos ser ouvido ou julgado pelos bispos que foram habilitados por Deus a julgá-lo em seu nome. ${ }^{38}$

Hincmar revela absoluta independência diante do soberano e do papa, que pretendia imiscuir-se nos problemas da monarquia carolíngia. Suas relações com o papado não são fáceis. Ele não aceita um poder discricionário dos papas. Reconhece o privilegium do primado "mas deseja que ele se exerça no respeito às estruturas e da disciplina dispostas por Deus para regular a vida de sua Igreja e assegurar a pax ecclesiastica. ${ }^{39}$ Assim é que, absolutamente convencido da inocência do rei Carlos, o Calvo, recusa-se a aceitar a excomunhão desejada por Adriano II. A atitude do arcebispo revela sua fidelidade à idéia de que obedecer ao rei que é realmente rei, é obedecer a Deus. Mas reflete nitidamente a tradicional hostilidade do clero carolíngio a qualquer intervenção papal nas coisas do reino. Registre-se, por outro lado, que nunca se proclamou com tanta firmeza a independência dos dois ofícios.

Essa pretensão episcopal de exercer uma autoridade e uma total independência diante do Estado estende-se ao século $\mathrm{X}$ e início do seguinte. $\mathrm{O}$ sistema episcopal, que se inaugura depois de 814 e se consolida sobretudo a partir do sinodo de Paris (829) - cujo principal nome foi o bispo Jonas de Orleans - dará sempre ênfase à superioridade do poder espiritual e sublinhará que a Igreja detém um poder mais perfeito que os outros.

A capacidade de intervenção do episcopado nos negócios do Estado na época carolíngia mostra bem que o programa hierocrático segue vitorioso curso. A considerável riqueza territorial da Igreja franca - terras recebidas do rei, de poderosos aristocratas e de pequenos camponeses - dera ao clero local grande poder e ao papado imenso trabalho. A atitude dos bispos continha, porém, uma estranha contradição: ao mesmo tempo em que se opunham à Sé Apostólica, apoiavam-se na autoridade do pontífice romano para manterem sua posição contra a jurisdição temporal.

38 "A qua consecratione vel regni sublimitate subplantari vel proici a nullo debueram, saltem sine audientia et judicio episcoponum quorum ministerio in regem sum consecratus et qui throni Dei sunt dicti, in quibus Deus sedet et per quos sua decemit judicia; quorum correptionibus et castigariis judiciis me subdere fui paternis paratus et in praesenti sum paratus" (Cap II, 451). M. David, com base neste texto de Carlos, o Calvo, que transcreve em nota, e analisando pronunciamentos de Hincmar, inclina-se a aceitar que os reis possam ser julgados e depostos pelos bispos (M. DAVID. La souveraineté... p. 125). J. Devisse refuta o argumento. Afirma que o arcebispo de Reims năo considerava essa hipótese. Não se trata absolutamente "de um julgamento no sentido juridico do termo, mas da eventual imposição de uma penitência, cujo efeito poderia ser, ou não, o abandono do cargo pelo rei penitente". J. DEVISSE. Op. cit., p. 707, n. 208. Como M. David, J. Paul (Op. cit. p. 72, n. 2) acredita ser evidente a influência do pensamento de Hincmar no texto real. Note-se que, ao invocar sua auctoritas para justificar seu direito de julgar um soberano, o clero sempre procurou cercar sua atitude de um caráter meramente religioso e moral. Todavia, o próprio Hincmar demonstrava sentir que a doutrina jurídica não podia repousar em preceitos exclusivamente teológicos.

Y. CONGAR. Op. cit. p. 174. 


\section{Conclusão}

A ideologia da substituição do Estado pela Igreja dá origem à elaboração de uma teoria do Império Cristão. O Império Carolíngio é a encarnação dessa idealização, e Carlos Magno (para alguns) a resposta ao ideal de Santo Agostinho. No reinado do fraco imperador Luís, filho e sucessor de Carlos Magno, o episcopado assume papel de relevo e dita normas. Os bispos tornam-se conselheiros dos reis. Ao invocar a sua auctoritas para julgar os monarcas, o clero carolíngio dá origem a elementos doutrinários esparsos e contraditórios, mas de indiscutivel importância para o estudo do pensamento político. A ideologia episcopal irá alimentar por longo tempo o sonho de uma restauração carolíngia e impregnar o Estado Feudal. Releva observar ainda que o sistema hierocrático é o prenúncio da teocracia pontifícia. De resto, assinale-se que essas disputas em que mergulhou o Ocidente propiciaram 0 desenvolvimento da doutrina da monarquia papal. Gradualmente fortalecida, Roma pode afirmar a supremacia moral do papa sobre o monarca e submeter os bispos à sua autoridade. A Sé Apostólica inicia a escalada que vai culminar com a vitória da plenitudo potestatis papal a partir do século XI. 